\title{
Dissemination of multiresistant Enterobacter cloacae isolates producing OXA-48 and CTX-M-15 in a Spanish hospital
}

\author{
Javier Fernández ${ }^{\mathrm{a}, \mathrm{b}}$, Ignacio Montero ${ }^{\mathrm{a}}$, Óscar Martínez ${ }^{\mathrm{b}}$, Ana Fleites ${ }^{\mathrm{b}}$, Laurent Poirel ${ }^{\mathrm{c}}$, \\ Patrice Nordmann ${ }^{\mathrm{c}, \mathrm{d}}$, M. Rosario Rodicio ${ }^{\mathrm{a}, *}$ \\ a Department of Functional Biology, Section of Microbiology, University of Oviedo, Oviedo, Spain \\ bervice of Microbiology, Hospital Universitario Central de Asturias, Oviedo, Spain \\ ${ }^{c}$ Medical and Molecular Microbiology, 'Emerging Antibiotic Resistance' Unit, Department of Medicine, Faculty of Science, University of Fribourg, Fribourg, \\ Switzerland \\ ${ }^{\mathrm{d}}$ HFR - Hôpital Cantonal, Fribourg, Switzerland
}

Twenty-one multiresistant Enterobacter cloacae isolates producing OXA-48 ( $n=10)$, CTX-M-15 ( $n=7)$ or both $(n=4) \beta$-lactamases were detected in a Spanish hospital during a 1-year period (June 2013 to June 2014). The isolates were also resistant to non- $\beta$-lactam antimicrobials, further complicating the therapeutic options. Genotyping of the isolates identified two major clones (ST74 and ST66) that caused prolonged outbreaks in different buildings of the hospital as well as some sporadic isolates (ST78, ST45 and ST295). Isolates belonging to clone $1(n=7)$ were carbapenem-resistant and carried the bla $a_{\mathrm{OXA}-48}$ gene on a conjugative IncL/M plasmid of ca. $65 \mathrm{~kb}$. Clone 2 isolates $(n=11)$ were resistant to cefepime and harboured the bla $a_{\mathrm{CTX}-\mathrm{M}-15}$ gene on an ca. $150-\mathrm{kb}$, non-conjugative plasmid of the IncF group, co-harbouring the $q \operatorname{nrB}$ and $a a c\left(6^{\prime}\right)-I b$-cr genes encoding quinolone resistance. Four clone 2 isolates were also resistant to carbapenems owing to the co-production of OXA-48. Most of the isolates were recovered from critically ill patients and were admitted to intensive care units; a single patient was transferred from another Spanish hospital. Intrahospital and interhospital dissemination of multiresistant E. cloacae isolates is of major clinical concern as it could lead to endemic nosocomial situations.

\section{Introduction}

Enterobacter cloacae is an opportunistic pathogen frequently involved in nosocomial infections [1]. This enterobacterial species is intrinsically resistant to aminopenicillins, amoxicillin/clavulanic acid (AMC) and cephalosporins of early generations owing to a chromosomally encoded AmpC $\beta$-lactamase. Isolates overproducing $A m p C$ are also resistant to broad-spectrum cephalosporins. Furthermore, E. cloacae has the ability to acquire additional resistance mechanisms, including plasmid-encoded extendedspectrum $\beta$-lactamases (ESBLs) and carbapenemases [1]. Phenotypic detection of ESBL production may be difficult since it can be masked by overexpression of AmpC. Some E. cloacae isolates may also exhibit permeability defects due to the absence of porins or porin mutations, further increasing the minimum inhibitory

* Corresponding author at: Departamento de Biología Funcional, Área de Microbiología, Universidad de Oviedo, Facultad de Medicina, Julián Clavería 6, 33006 Oviedo, Spain. Tel.: +34985103562.

E-mail address: rrodicio@uniovi.es (M.R. Rodicio). concentrations (MICs) of $\beta$-lactams and carbapenems, particularly ertapenem [1].

In members of the Enterobacteriaceae family, CTX-M-15 and OXA-48 are among the most common enzymes involved in resistance to broad-spectrum cephalosporins and carbapenems, respectively $[2,3]$. CTX-M-15 is a class A ESBL encoded by the bla $_{\text {CTX-M-15 }}$ gene, which has been identified in plasmids of varying size $(85-200 \mathrm{~kb})$ and structure, and often belonging to the FII incompatibility (Inc) group [4]. OXA-48 is an Ambler class D carbapenemase that confers resistance to penicillins and reduced susceptibility to carbapenems but does not significantly hydrolyse broad-spectrum cephalosporins [3]. The $b l a_{\text {OXA-48 }}$ gene has been almost always located on a conjugative plasmid of ca. $62 \mathrm{~kb}$ assigned to the IncL/M group and has been identified only in enterobacterial species [5,6]. Both CTX-M-15 and OXA-48 have been detected in several enterobacterial species, being particularly frequent in Klebsiella pneumoniae, whilst they are relatively uncommon in E. cloacae [2,3]. Here we report the clinical and genetic features of $21 \mathrm{E}$. cloacae isolates producing CTX-M-15, OXA-48 or both, which were mainly recovered from critically ill patients, in a Spanish hospital during a 1-year period. 


\section{Patients and methods}

\subsection{Setting, patients and bacterial isolates}

'Hospital Universitario Central de Asturias' (HUCA) (Oviedo, Spain) is a 1100-bed university hospital providing care for a population of ca. 342,000 inhabitants in the Asturias region of northern Spain. During the 1-year period from June 2013 to June 2014, all E. cloacae isolates recovered at the hospital $(n=448)$ were analysed phenotypically for production of carbapenemases and ESBLs. A total of 21 multiresistant isolates, all recovered from different patients, produced a carbapenemase, an ESBL or both. Most E. cloacae isolates were obtained from critically ill patients admitted to two intensive care units (ICU1 and ICU2) located in different buildings or to other hospital wards. Relevant features regarding the patients are shown in Table 1.

\subsection{Susceptibility testing}

All E. cloacae isolates underwent antimicrobial susceptibility testing by the disc diffusion assay (Becton Dickinson, Sparks, MD). The MicroScan ${ }^{\circledR}$ system (Neg Combo Panel Type 53; Siemens Healthcare Diagnostics, Deerfield, IL) was used for determination of MICs and for bacterial identification, and the latter was confirmed by matrix-assisted laser desorption/ionisation time-offlight mass spectrometry (MALDI-TOF/MS) (microflex ${ }^{\mathrm{TM}}$; Bruker Daltonik GmbH, Bremen, Germany). Results of disc diffusion assays and MICs were interpreted according to Clinical and Laboratory Standards Institute (CLSI) breakpoints updated in January 2014 [7]. Etest strips (bioMérieux, Marcy-l'Étoile, France) were used for determining the MICs of ertapenem and imipenem in those isolates suspected of carbapenemase production. The Carba NP test recommended for detection of carbapenemases [8] was also performed for isolates with elevated MICs of ertapenem and imipenem. All E. cloacae suspected of ESBL production (double-disc synergy test positive and/or elevated MIC to cefepime) were tested with the cefepime/cefepime + clavulanic acid (PM/PML) Etest (bioMérieux).

\subsection{Identification of genes encoding extended-spectrum}

$\beta$-lactamases and carbapenemases, and plasmid analysis

Genes encoding resistance to broad-spectrum cephalosporins (bla $a_{\mathrm{TEM}}, b l a_{\mathrm{SHV}}$ and $\left.b l a_{\mathrm{CTX}-\mathrm{M}}\right)$ and carbapenems (bla $\left.{ }_{\mathrm{OXA}-48}\right)$ were identified by PCR amplification [5] followed by sequencing. Transposon Tn1999 (known to carry the bla OXA-48 gene) and plasmid-mediated quinolone resistance genes [qnrA, qnrB, qnrS and $\left.\operatorname{aac}\left(6^{\prime}\right)-I b-\mathrm{cr}\right]$ were searched by PCR amplification followed by sequencing of the obtained products $[3,9]$. Plasmid DNA was extracted by the Kado and Liu method [5] and was visualised by agarose gel electrophoresis.

Plasmid Inc groups were determined by PCR-based replicon typing [5]. Conjugation experiments were performed using as donor isolates representatives of three antibiotic resistance phenotypes, namely resistance to carbapenems but susceptibility to cefepime (Ecl10), resistance to cefepime but susceptibility to carbapenems (Ecl8 and Ecl9), or resistance to both (Ecl15). A rifampicin-resistant Escherichia coli J53 strain was used as recipient for conjugation assays. Transconjugants were selected on eosin-methylene blue agar (Oxoid, Madrid, Spain) containing rifampicin (100 mg/L) plus ertapenem $(0.5 \mathrm{mg} / \mathrm{L})$ or rifampicin plus ceftriaxone $(10 \mathrm{mg} / \mathrm{L})$. Plasmid DNA extracted from each of the donor E. cloacae and their transconjugants was transferred to a nylon membrane and was then hybridised with probes specific for the bla $a_{\text {CTX-M-15 }}$ and bla $a_{\text {OXA-48 }}$ genes. Probes were labelled using the PCR DIG Labeling Mix (Roche Applied Science, Penzberg, Germany), followed by gel extraction with the GFX ${ }^{\mathrm{TM}}$ DNA and Gel Band Purification Kit (Amersham Biosciences, Little Chalfont, UK).

\subsection{Pulsed-field gel electrophoresis (PFGE) analysis}

Total DNA from the $21 \mathrm{E}$. cloacae isolates was digested with Xbal (Takara Bio Europe, Saint-Germain-en-Laye, France; 30U, $4 \mathrm{~h}$ at $\left.37^{\circ} \mathrm{C}\right)$. The generated fragments were separated by PFGE using a CHEF-DR III System (Bio-Rad Laboratories, Hercules, CA) under the conditions recommended by PulseNet (http://www. pulsenetinternational.org). Similarity between Xbal profiles was evaluated by the Jaccard's coefficient $(S)$, and cluster analysis was performed by the unweighted pair-group method with arithmetic averages (UPGMA) using the software program MVSP (Multivariate Statistical Package for PCs; RockWare Inc., Golden, CO).

\subsection{Multilocus sequence typing (MLST)}

MLST was performed for representative isolates with different PFGE profiles (Ecl10, Ecl3, Ecl9, Ecl8, Ecl21, Ecl5 and Ecl7) as described previously [10]. The database available at http://pubmlst. org/ecloacae was used for assigning sequence types (STs).

\section{Results}

\subsection{Antimicrobial susceptibility and genetic basis for resistance to broad-spectrum cephalosporins and carbapenems}

As shown in Table 2, 20 of the 21 E. cloacae isolates were resistant to cefotaxime and 11 were also resistant to cefepime. Moreover, 14 isolates displayed intermediate susceptibility or resistance to carbapenems. In addition to $\beta$-lactam antibiotics, all E. cloacae isolates were variably resistant to other antimicrobial groups, including quinolones (nalidixic acid and ciprofloxacin), aminoglycosides (gentamicin and tobramycin) and trimethoprim/sulfamethoxazole.

The bla $_{\mathrm{CTX}-\mathrm{M}-15}$ gene was detected in all isolates resistant to cefepime and positive for the PM/PML test $(n=11)$, whilst the $b_{1} a_{\text {OXA-48 }}$ gene was found in all isolates with elevated MICs of imipenem and positive for the Carba NP test $(n=14)$. Both bla $a_{\mathrm{CTX}-\mathrm{M}-15}$ and $b l a_{\mathrm{OXA}-48}$ were identified in four isolates. Overall, isolates harbouring bla $a_{\mathrm{CTX}-\mathrm{M}-15}, b l a_{\mathrm{OXA}-48}$ or both accounted for $1.6 \%, 2.2 \%$ and $0.9 \%$ of the total number of $E$. cloacae recovered in HUCA over the 1-year study period ( $n=448)$.

The genetic location of $b l a_{\mathrm{CTX}-\mathrm{M}-15}$ and $b l a_{\mathrm{OXA}-48}$ was established by plasmid analysis, hybridisation and conjugation experiments. As shown in Fig. 1A and Table 2, all ESBL-producers carried a plasmid of ca. $150 \mathrm{~kb}$ hybridising with the bla $a_{\mathrm{CTX}-\mathrm{M}-15}$ probe and belonging to the IncF group. Furthermore, all imipenem-resistant isolates harboured a common plasmid of ca. $65 \mathrm{~kb}$ that gave a positive hybridisation signal with the bla $_{\mathrm{OXA}-48}$ probe and belonged to the IncL/M group. Noteworthy, the bla OXA-48 gene was always identified in transposon $\operatorname{Tn} 1999.1$.

To investigate the potential of transfer of the IncF and IncL/M plasmids carrying the bla $a_{\mathrm{CTX}-\mathrm{M}-15}$ and $b l a_{\mathrm{OXA}-48}$ genes, conjugation experiments were performed using Ecl8 and Ecl9 (bla $a_{\mathrm{CTX}-\mathrm{M}-15}$ ), Ecl10 (bla OXA-48) and Ecl15 (bla $a_{\mathrm{CTX}-\mathrm{M}-15}$ and $\left.b l a_{\text {OXA-48 }}\right)$ as donors. When selection was performed with ertapenem, E. coli transconjugants were readily obtained both from Ecl10 and Ecl15 donor strains. Three independent $E$. coli transconjugants analysed from each mating experiment showed resistance to ampicillin, AMC and ertapenem, were positive by PCR for the $b l a_{\mathrm{OXA}-48}$ gene and carried an ca. $65 \mathrm{~kb}$ plasmid (Fig. 1A; Table 2). By contrast, no transconjugants were obtained after three independent conjugations using Ecl8 and Ecl9 as donors and ceftriaxone as selective agent, and only two transconjugants after the same number of 
Table 1

Features of the 21 patients infected or colonised by multiresistant Enterobacter cloacae isolates.

\begin{tabular}{|c|c|c|c|c|c|c|c|}
\hline Patient & Sex/age (years) & Hospital unit & $\begin{array}{l}\text { Admission } \\
\text { diagnosis/colonisation or } \\
\text { infection type }\end{array}$ & Sample origin & $\begin{array}{l}\text { Date of } \\
\text { isolation }\end{array}$ & Treatment & Outcome \\
\hline 1 & $\mathrm{M} / 46$ & ICU1 & $\begin{array}{l}\text { Pancreatitis/surgical } \\
\text { wound infection }\end{array}$ & Wound exudate & $25 / 06 / 2013$ & Tobramycin & Discharged \\
\hline 2 & $\mathrm{~F} / 56$ & ICU1 & Lung cancer/pneumonia & Lung necropsy & $26 / 06 / 2013$ & TZP & Died \\
\hline 3 & $\mathrm{~F} / 77$ & ICU2 & $\begin{array}{l}\text { Cardiac surgery/respiratory } \\
\text { colonisation }\end{array}$ & $\begin{array}{l}\text { Tracheobronchial } \\
\text { aspirate }\end{array}$ & $5 / 07 / 2013$ & Untreated & Discharged \\
\hline 4 & $\mathrm{M} / 19$ & ICU1 & $\begin{array}{l}\text { Severe head injury/urinary } \\
\text { tract infection }\end{array}$ & Urine & $12 / 08 / 2013$ & Ciprofloxacin & Died \\
\hline 5 & $\mathrm{M} / 81$ & Reanimation & $\begin{array}{l}\text { Vascular } \\
\text { surgery/respiratory } \\
\text { infection }\end{array}$ & $\begin{array}{l}\text { Tracheobronchial } \\
\text { aspirate }\end{array}$ & $23 / 12 / 2013$ & $\begin{array}{l}\text { Ciprofloxacin/ } \\
\text { gentamicin/meropenem }\end{array}$ & Died \\
\hline 6 & $\mathrm{M} / 81$ & ICU2 & $\begin{array}{l}\text { Vascular } \\
\text { surgery/pneumonia }\end{array}$ & $\begin{array}{l}\text { Tracheobronchial } \\
\text { aspirate }\end{array}$ & $26 / 12 / 2013$ & Imipenem & Discharged \\
\hline 7 & $\mathrm{M} / 76$ & General surgery & $\begin{array}{l}\text { Abdominal } \\
\text { surgery/surgical wound } \\
\text { infection }\end{array}$ & Wound exudate & $27 / 12 / 2013$ & TZP & Discharged \\
\hline $8^{a}$ & $\mathrm{~F} / 57$ & Pneumology unit & $\begin{array}{l}\text { Lung transplantation } \\
\text { follow-up/respiratory } \\
\text { infection }\end{array}$ & Sputum & $17 / 01 / 2014$ & Amikacin/meropenem & Discharged \\
\hline 9 & $\mathrm{M} / 41$ & ICU2 & Septic shock/pneumonia & $\begin{array}{l}\text { Tracheobronchial } \\
\text { aspirate }\end{array}$ & $21 / 01 / 2014$ & Meropenem & Discharged \\
\hline 10 & $F / 33$ & ICU1 & $\begin{array}{l}\text { H1N1 flu } \\
\text { pneumonia/respiratory } \\
\text { colonisation }\end{array}$ & $\begin{array}{l}\text { Tracheobronchial } \\
\text { aspirate }\end{array}$ & $23 / 01 / 2014$ & Untreated $^{\mathrm{b}}$ & Discharged \\
\hline 11 & $\mathrm{~F} / 53$ & ICU1 & $\begin{array}{l}\text { H1N1 flu } \\
\text { pneumonia/respiratory } \\
\text { colonisation }\end{array}$ & $\begin{array}{l}\text { Tracheobronchial } \\
\text { aspirate }\end{array}$ & $27 / 01 / 2014$ & Untreated $^{\mathrm{b}}$ & Discharged \\
\hline 12 & $\mathrm{M} / 79$ & Cardiac surgery & $\begin{array}{l}\text { Cardiac surgery/urinary } \\
\text { tract infection }\end{array}$ & Urine $^{\mathrm{c}}$ & $29 / 01 / 2014$ & SXT & Discharged \\
\hline 13 & $\mathrm{M} / 36$ & ICU2 & $\begin{array}{l}\text { H1N1 flu } \\
\text { pneumonia/pneumonia }\end{array}$ & Pleural fluid & $11 / 02 / 2014$ & $\mathrm{TZP} /$ colistin $^{\mathrm{b}}$ & Died \\
\hline 14 & $\mathrm{M} / 62$ & Cardiac surgery & $\begin{array}{l}\text { Cardiac } \\
\text { surgery/asymptomatic } \\
\text { bacteriuria }\end{array}$ & Urine & $17 / 02 / 2014$ & Untreated & Discharged \\
\hline 15 & $F / 30$ & Cardiology & $\begin{array}{l}\text { Heart } \\
\text { transplantation/surgical } \\
\text { wound infection }\end{array}$ & Wound exudate & $19 / 02 / 2014$ & Colistin/tigecycline & Discharged \\
\hline 16 & $F / 61$ & ICU2 & $\begin{array}{l}\text { Cardiac surgery/surgical } \\
\text { wound infection }\end{array}$ & Wound exudate & $17 / 03 / 2014$ & Imipenem & Discharged \\
\hline 17 & $\mathrm{~F} / 66$ & Internal medicine & $\begin{array}{l}\text { Respiratory } \\
\text { failure/asymptomatic } \\
\text { bacteriuria }\end{array}$ & Urine & $24 / 03 / 2014$ & Untreated & Discharged \\
\hline 18 & $\mathrm{M} / 69$ & Neurology & $\begin{array}{l}\text { Epileptic attack/urinary } \\
\text { catheter colonisation }\end{array}$ & Urine & $24 / 04 / 2014$ & Untreated & Discharged \\
\hline 19 & $\mathrm{~F} / 92$ & $\begin{array}{l}\text { Maxillofacial } \\
\text { surgery }\end{array}$ & $\begin{array}{l}\text { Maxillofacial } \\
\text { surgery/urinary tract } \\
\text { infection }\end{array}$ & Urine & $29 / 04 / 2014$ & Meropenem & Discharged \\
\hline 20 & $\mathrm{M} / 66$ & Cardiac surgery & $\begin{array}{l}\text { Cardiac surgery/surgical } \\
\text { wound infection }\end{array}$ & Wound exudate & $13 / 05 / 2014$ & Unknown $^{\mathrm{d}}$ & Discharged \\
\hline 21 & $\mathrm{M} / 79$ & ICU2 & $\begin{array}{l}\text { Vascular surgery/catheter } \\
\text { sepsis }\end{array}$ & Catheter tip & $14 / 05 / 2014$ & Imipenem & Discharged \\
\hline
\end{tabular}

ICU, intensive care unit; TZP, piperacillin/tazobactam; SXT, trimethoprim/sulfamethoxazole.

a Patient transferred from another hospital in a nearby region, where the E. cloacae infection had already been diagnosed.

b Patients 10, 11 and 13 were treated with oseltamivir.

c Another E. cloacae isolate with a different resistance pattern and not producing extended-spectrum $\beta$-lactamase (ESBL) or OXA-48 was detected in the same sample.

d The sample from this patient was collected in a primary care centre a few days after have being discharged of the Cardiac Surgery Unit of the hospital. There are no treatment data for this patient.

matings and ceftriaxone selection using Ecl15 as donor. Both Ecl15 transconjugants were resistant to ampicillin, AMC, broadspectrum cephalosporins and aminoglycosides, had an elevated MIC of ciprofloxacin and carried two plasmids, one of ca. $150 \mathrm{~kb}$ and the other slightly larger than $65 \mathrm{~kb}$, which hybridised with the bla $_{\mathrm{CTX}-\mathrm{M}-15}$ and $b l a_{\text {OXA-48 }}$ probes, respectively (Fig. $1 \mathrm{~A}$; Table 2). The latter could have derived from the ca. $65 \mathrm{~kb}$ plasmid through acquisition of additional DNA. Taken together, these results strongly suggest that the ca. $150 \mathrm{~kb}$ IncF plasmid carrying bla $a_{\mathrm{CTX}-\mathrm{M}-15}$ is not self-transferable, but it could be mobilised by the ca. $65 \mathrm{~kb}$ plasmid though at a rather low frequency. The qnrB and $a a c\left(6^{\prime}\right)-I b-c r$ genes were detected in the Ecl15 transconjugants as well as in the E. cloacae isolates carrying the IncF plasmid, all with decreased susceptibility to ciprofloxacin.

\subsection{Genotyping of the CTX-M-15- and/or OXA-48-producing Enterobacter cloacae isolates}

Typing of the 21 E. cloacae isolates by PFGE yielded seven profiles (X1-X7) (Fig. 1B). A dendrogram of similarity based on these profiles revealed two main clusters of E. cloacae (clusters I and II) that were strongly associated with the two separate buildings of HUCA (Fig. 1C). Cluster I comprised two profiles (X1 and $\mathrm{X} 5$ ) with seven and one isolates, respectively. A representative X1 
Table 2

Microbiological characteristics of clinical Enterobacter cloacae isolates and their transconjugants.

\begin{tabular}{|c|c|c|c|c|c|c|}
\hline Isolate ${ }^{a, b}$ & $\begin{array}{l}\text { Antimicrobial resistance } \\
\text { phenotype }\end{array}$ & $\begin{array}{l}\text { ESBL/CARB } \\
\text { gene }\end{array}$ & $\begin{array}{l}\text { ERT/IPM MIC } \\
(\mathrm{mg} / \mathrm{L})\end{array}$ & $\begin{array}{l}\text { Corresponding } \\
\text { plasmids }\end{array}$ & $\begin{array}{l}\text { PFGE profile/ } \\
\text { cluster/building }\end{array}$ & MLST \\
\hline $\begin{array}{l}\text { Ecl1, Ecl2, Ecl4, Ecl10, } \\
\text { Ecl11, Ecl17, Ecl18 }\end{array}$ & $\begin{array}{l}\text { AMX-AMC-FOX-CTX-ERT-IPM- } \\
\text { NAL-CIP-SXT }\end{array}$ & $b l a_{\mathrm{OXA}-48}$ & $4 / 2$ & $65 \mathrm{~kb}^{\mathrm{d}}$ & $\mathrm{X} 1 / \mathrm{I} / 1$ & ST74 \\
\hline Tc-Ecl10-ERT (1, 2 and 3) & AMX-AMC-ERT & $b l a_{\mathrm{OXA}-48}$ & $2 / 0.5$ & $65 \mathrm{~kb}^{\mathrm{d}}$ & $\mathrm{N} / \mathrm{A}$ & $\mathrm{N} / \mathrm{A}$ \\
\hline$\underline{\mathrm{Ecl} 3}$ & $\begin{array}{l}\text { AMX-AMC-FOX-CTX-GEN-ERT- } \\
\text { IPM-NAL-CIP-SXT }\end{array}$ & $b l a_{\mathrm{OXA}-48}$ & $3 / 2$ & $65 \mathrm{~kb}^{\mathrm{d}}$ & $\mathrm{X} 5 / \mathrm{I} / 2$ & ST78 \\
\hline $\begin{array}{l}\text { Ecl6, Ecl12, Ecl14, Ecl16, } \\
\text { Ecl20 }\end{array}$ & $\begin{array}{l}\text { AMX-AMC-FOX-CTX-FEP-GEN- } \\
\text { TOB-NAL-CIPe }\end{array}$ & $b l a_{\mathrm{CTX}-\mathrm{M}-15}$ & $\leq 0.5 / \leq 1$ & $150 \mathrm{~kb}^{\mathrm{f}}$ & $\mathrm{X} 2 / \mathrm{II} / 2$ & ST66 \\
\hline Ecl9 & & & & & $\mathrm{X} 3 / \mathrm{II} / 2$ & \\
\hline$\underline{\text { Ecl8 }}$ & $\begin{array}{l}\text { AMX-AMC-FOX-CTX-FEP-GEN- } \\
\text { TOB-NAL-CIPe-SXT }\end{array}$ & $b l a_{\mathrm{CTX}-\mathrm{M}-15}$ & $\leq 0.5 / \leq 1$ & $150 \mathrm{~kb}^{\mathrm{f}}$ & $\mathrm{X} 4 / \mathrm{II} / 1$ & ST66 \\
\hline Ecl19, Ecl21 & $\begin{array}{l}\text { AMX-AMC-FOX-CTX-FEP-ERT- } \\
\text { IPM-GEN-TOB-NAL-CIP }\end{array}$ & $\begin{array}{l}\text { bla }_{\mathrm{CTX}-\mathrm{M}-15} \\
\text { bla }_{\mathrm{OXA}-48}\end{array}$ & $4-6 / 2-4$ & $150 \mathrm{~kb}^{\mathrm{f}}, 65 \mathrm{~kb}^{\mathrm{d}}$ & $\mathrm{X} 2 / \mathrm{II} / 2$ & ST66 \\
\hline Ecl13, Ecl15 & & & & & $\mathrm{X} 3 / \mathrm{II} / 2$ & \\
\hline Tc-Ecl15-ERT (1, 2 and 3) & AMX-AMC-ERT & $b l a_{\mathrm{OXA}-48}$ & $2 / 0.5$ & $65 \mathrm{~kb}^{\mathrm{d}}$ & $\mathrm{N} / \mathrm{A}$ & $\mathrm{N} / \mathrm{A}$ \\
\hline Tc-Ecl15-CRO (1 and 2) & $\begin{array}{l}\text { AMX-AMC-CTX-FEP-ERT-GEN- } \\
\text { TOB-CIPe }\end{array}$ & $\begin{array}{l}\text { bla }_{\mathrm{CTX}-\mathrm{M}-15} \\
\text { bla }_{\mathrm{OXA}-48}\end{array}$ & $1 / 0.38$ & $\begin{array}{l}150 \mathrm{~kb}^{\mathrm{f}} \\
>65 \mathrm{~kb}^{\mathrm{d}}\end{array}$ & $\mathrm{N} / \mathrm{A}$ & $\mathrm{N} / \mathrm{A}$ \\
\hline$\underline{\text { Ecl5 }}$ & $\begin{array}{l}\text { AMX-AMC-FOX-ERT-IPM-NAL- } \\
\text { CIP-SXT }\end{array}$ & $b l a_{\mathrm{OXA}-48}$ & $4 / 4$ & $65 \mathrm{~kb}^{\mathrm{d}}$ & $\mathrm{x} 6 /-/ 1$ & ST45 \\
\hline$\underline{\text { Ecl7 }}$ & $\begin{array}{l}\text { AMX-AMC-FOX-CTX-ERT-IPM- } \\
\text { GEN-TOB-NAL-CIP-SXT }\end{array}$ & $b l a_{\mathrm{OXA}-48}$ & $8 / 4$ & $65 \mathrm{~kb}^{\mathrm{d}}$ & $\mathrm{X} 7 /-/ 1$ & ST295 \\
\hline
\end{tabular}

ESBL, extended-spectrum $\beta$-lactamase; CARB, carbapenemase; MIC, minimum inhibitory concentration; PFGE, pulsed-field gel electrophoresis; MLST, multilocus sequence type; AMX, amoxicillin; AMC, amoxicillin/clavulanic acid; FOX, cefoxitin; CTX, cefotaxime; ERT, ertapenem; IPM, imipenem; NAL, nalidixic acid; CIP, ciprofloxacin; SXT, trimethoprim/sulfamethoxazole; GEN, gentamicin; FEP, cefepime; TOB, tobramycin; CRO, ceftriaxone; N/A, not applicable.

a Enterobacter cloacae (Ecl) isolates with numbers corresponding to patient numbers in Table 1. Ecl isolates used as donors in conjugation experiments are shown in bold. Ecl isolates for which the MLST was determined are underlined.

b Escherichia coli transconjugants designated with Tc followed by the E. cloacae donor isolate and the antimicrobial used for selection: ERT (ertapenem) or CRO (ceftriaxone); the number of transconjugants tested is shown in parenthesis. No transconjugants were obtained for Ecl9 and Ecl8 after selection with CRO.

c See Fig. 1C and text for details.

d IncL/M plasmids.

e Isolates positive for the $q n r B$ and $a a c\left(6^{\prime}\right)-I b$-cr genes.

f IncF plasmids.

isolate and the X5 isolate belonged to ST74 and ST78, respectively, within the same clonal complex (Fig. 1C; Table 2). All X1 isolates were recovered in building 1 , which houses the main ICU of the hospital (ICU1), where five of them were detected. The remaining two came from the internal medicine and neurology services. All isolates within cluster I were resistant to carbapenems owing to production of OXA-48 and all were also resistant to broad-spectrum cephalosporins, consistent with overexpression of the chromosomal $b a_{\mathrm{ampc}}$ gene. Cluster II was associated with a second building of the hospital encompassing the cardiac and maxillofacial surgery units and another ICU (ICU2). It included 11 isolates with identical (X2; 7 isolates) or closely related (X3 and $\mathrm{X} 4$, with 3 and 1 isolates, respectively) profiles assigned to ST66, and all except one (Ecl8; X4 profile) were recovered in building 2 (Fig. 1C; Table 2). Interestingly, Ecl8 was identified from a single patient who had been transferred from a hospital in the nearby region of Santander, where the $E$. cloacae infection had already been diagnosed. Isolates within cluster II were all resistant to broad-spectrum cephalosporins owing to the production of CTX-M-15, and 4 of the 11 isolates also harboured bla $_{\text {OXA-48 }}$ and were therefore resistant to carbapenems. Two distantly related profiles (X6 and X7) were shown by OXA-48producers belonging to ST45 and ST295, respectively, and found in building 1 (Fig. 1C; Table 2).

\section{Discussion}

Enterobacter cloacae isolates producing OXA-48, CTX-M-15 or both $\beta$-lactamases emerged as important pathogens in HUCA, a general university hospital in northern Spain. In fact, they accounted for $4.7 \%(21 / 448)$ of the total E. cloacae isolates recovered over a 1-year period, although they were not previously reported in this region. Together with some sporadic isolates, two major clones (ST74 and ST66, falling in two different clusters according to PFGE analysis) are causing prolonged outbreaks in separate buildings of the hospital. The ST74 clone consisted of carbapenem-resistant isolates carrying the bla $a_{\mathrm{OXA}-48}$ gene. This is the first outbreak caused by OXA-48-producing E. cloacae reported in Europe, but a previous outbreak has been noticed in a neonatal ICU in Jerusalem [11]. In contrast to that observed here, isolates from Israel carried a derivative of the OXA-48 plasmid that had acquired the $b l a_{\mathrm{CTX}-\mathrm{M}-14}$ gene. The second clone identi-

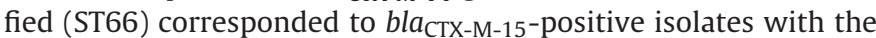
ESBL gene located on an ca. $150-\mathrm{kb}$, non-conjugative plasmid of the IncF group. Some of them co-harboured the IncL/M plasmid and co-produced OXA-48. Interestingly, one of the clone 2 isolates was apparently transferred from another hospital located in a nearby region of Spain, so in addition to intrahospital dissemination, interhospital spread is contributing to the emergence of CTX-M-15-producing E. cloacae in HUCA. Additional outbreaks of E. cloacae producing CTX-M-15 have occurred in a newborn ICU in Spain as well as in a children's hospital in Finland $[12,13]$.

Noticeably, some isolates belonging to clone 2 also carried the bla $a_{\text {OXA-48 }}$ plasmid, which could have been acquired from other OXA48-producing Enterobacteriaceae circulating in the hospital [5; our unpublished results]. This might be in accordance with the high frequency of dissemination of the bla $a_{\mathrm{OXA}-48}$-carrying plasmid as previously demonstrated [14]. 


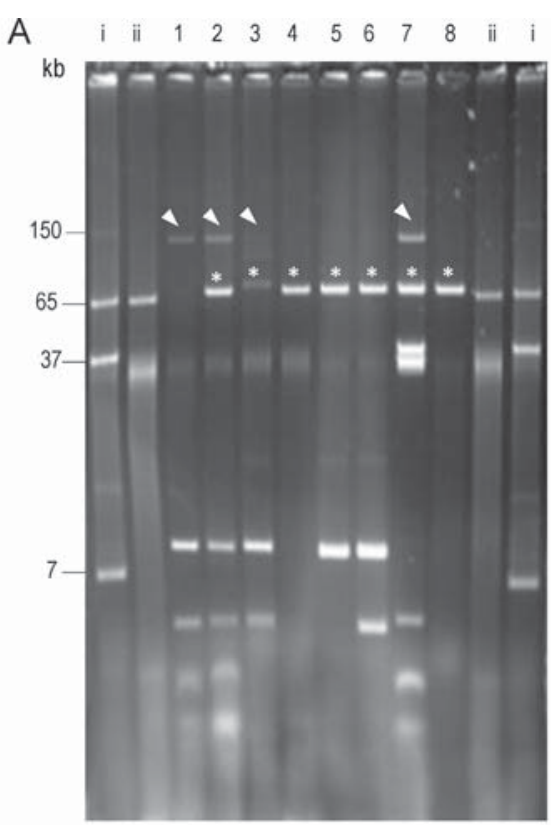

C

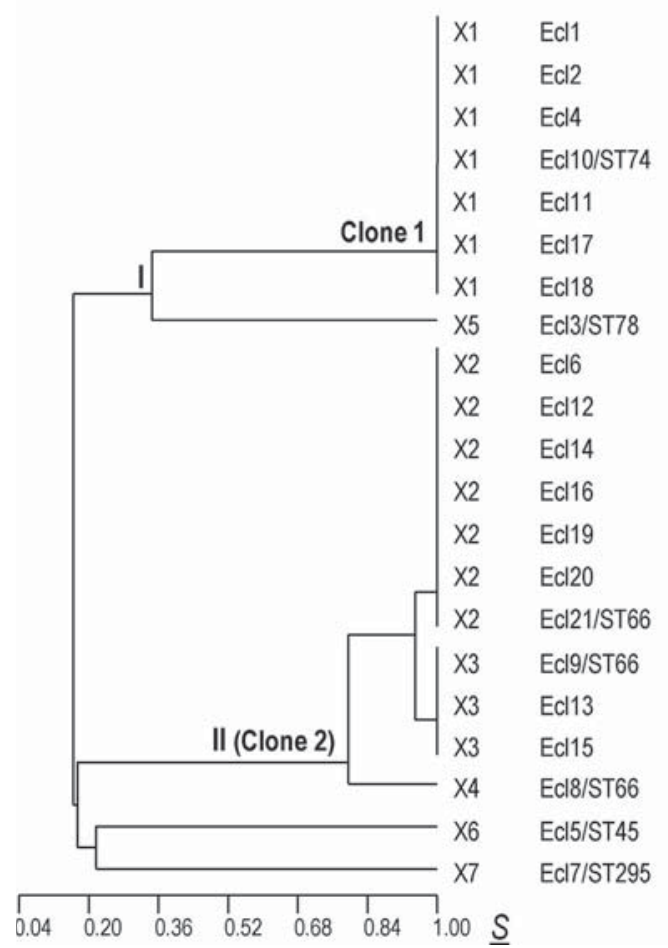

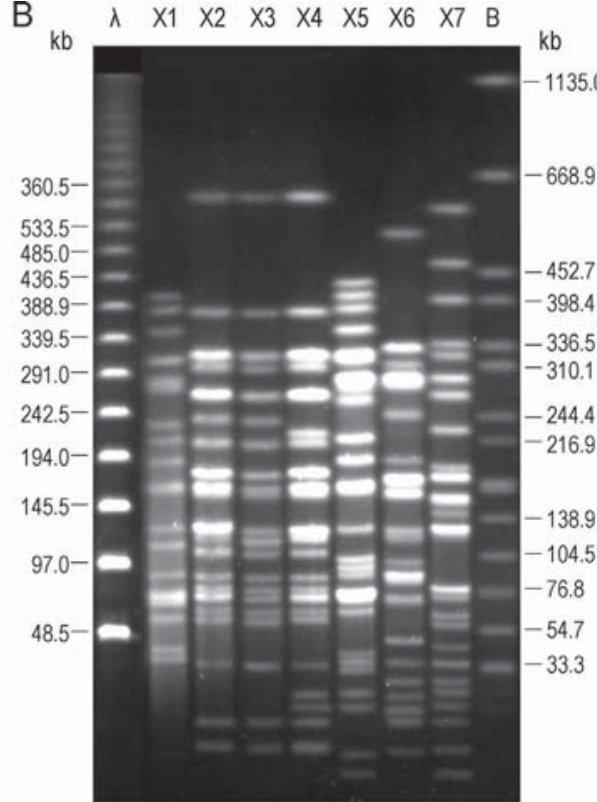

Hospital ward Building $\quad \beta$-lactamase gene(s) Plasmid Inc $\begin{array}{llll}\text { ICU1 } & 1 & \text { InCL/M }\end{array}$ ICU1 ICU1 ICU1 ICU1 Internal medicine Neurology ICU2 ICU2

Cardiac surgery

bla $a_{0 \times 4.48}$ IncL/M bla ${ }_{\text {OXA.48 }}$ IncL/M bla ${ }_{\text {OXA-48 }}$ bla $0 \times A-48$ bla OXA.48 bla $a_{0 \times A} 48$ bla OXA.48 bla CTX-M-15 bla CTX-M-15

bla CTX-M-15 $_{\text {- }}$ bla CTX-M-15 ac surgery

ICU2

bla CTX-M-15 $_{15}$ bla XXA-48 $_{1}$

bla CTX-M-15

bla $a_{\text {CTX-M-15 }}$, bla OXA.48

bla $\mathrm{C}_{\mathrm{CTX}-\mathrm{M}-15}$

bla $_{\text {CTX-M-15 }}$, bla OXA-48 IncF,IncL/M

bla CTX-M-15, $_{\text {, bla OXA.48 }}$ IncF,IncL/M

bla CTX-M-15

bla OXA.48 Neumology Reanimation General surgery

bla OXA-48 IncF

IncL/M

IncL/M

IncL/M

IncL/M

IncL/M

IncF

IncF

IncF

IncF

IncF, IncL/M

IncF

IncF, IncL/M

IncF

InCLM

IncL/M

Fig. 1. Molecular typing and genetic relationships of Enterobacter cloacae isolates producing OXA-48 and CTX-M-15 $\beta$-lactamases in a Spanish hospital. (A) Plasmid profiles of representative E. cloacae isolates and their transconjugants. Lanes i and ii, plasmids obtained from Escherichia coli 39R861 (NCTC 50192) and plasmid RP4 used as molecular size standards for uncut DNA; lane 1, Ecl9; lane 2, Ecl15; lane 3, Tc-Ecl15-CRO (1); lane 4, Tc-Ecl15-ERT (1); lane 5, Tc-Ecl15-ERT (2); lane 6, Tc-Ecl15-ERT (3); lanes 7 , Ecl10; and lane 8, Tc-Ecl10-ERT (1). Plasmids hybridising with bla $a_{\mathrm{CTX}-\mathrm{M}-15}$ and bla $\mathrm{OXA}_{48}$ probes are marked with arrowheads and asterisks, respectively. (B) Pulsed-field gel electrophoresis (PFGE) profiles generated from E. cloacae isolates by XbaI digestion. Lane $\lambda$, Lambda Ladder PFG Marker (New England Biolabs, Beverly, MA) and lane B, DNA from Salmonella enterica serovar Braenderup H9812 digested with XbaI, both used as size standards. Lane X1, Ecl10; lane X2, Ecl6; lane X3, Ecl9; lane X4, Ecl8; lane X5, Ecl3; lane X6, Ecl5; and lane X7, Ecl7. (C) Dendrogram of similarity showing the relatedness between the XbaI profiles. Isolates assigned to each profile as well as the hospital ward and building in which they were collected are shown. Relevant genes and plasmids carried by each isolate are also indicated. Clusters I and II comprise ST74 (clone 1)/ST78 (positive for $b l a_{\mathrm{OXA}-48}$ ) and ST66 (clone 2, positive for bla $a_{\mathrm{CTX}-\mathrm{M}-15} \pm b l a_{\mathrm{OXA}-48}$ ) isolates, respectively. X, XbaI profile; ST, sequence type; ICU, intensive care unit; Inc, incompatibility group; $\underline{S}$, Jaccard's coefficient of similarity.

Occurrence of the $q n r B$ and $\operatorname{aac}\left(6^{\prime}\right)$-Ib-cr genes in enterobacterial isolates producing OXA-48 or ESBLs, including some of the CTX-M-15-producing E. cloacae isolates causing the outbreak in a neonatal unit in Spain, was previously noticed [12].
Most E. cloacae reported in this study were assigned to STs previously associated with ESBL- and carbapenemase-producers and considered as high-risk international clones (ST45, ST66, ST74 and ST78), with the latter two belonging to the same clonal complex $[10,15]$. Noteworthy, none of these clones had been previously 
associated with OXA-48 production. Since phylogenetic studies on multiresistant $E$. cloacae have been initiated only recently, further studies are required to expand the knowledge of these multiresistant bacteria.

Although the number of $E$. cloacae producing carbapenemases or ESBLs has increased in recent years, their real prevalence could be underestimated because of difficulties in detecting both $\beta$ lactamases. In the present study, the Carba NP test proved to be very efficient for accurate identification of carbapenemase-producers.

\section{Conclusions}

Intrahospital and interhospital dissemination of multiresistant E. cloacae isolates producing CTX-M-15, OXA-48 or both $\beta$-lactamases is a cause of concern due to the limited options remaining for the treatment of affected patients, most with critical underlying conditions. Interestingly, as observed for $K$. pneumoniae, emergence of both broad-spectrum resistance traits in single E. cloacae isolates corresponds to the transfer of genes having disseminated from community pathogens into nosocomial pathogens. Considering that the community reservoir of some of these resistance traits is significantly growing nowadays, the likelihood of witnessing an increased number of nosocomial outbreaks due to multiresistant $E$. cloacae is very high.

Funding: This work has been supported by project FIS-PI1100808 (Fondo de Investigación Sanitaria, Instituto de Salud Carlos III, Ministerio de Economía y Competitividad, Spain), co-funded by the European Regional Development Fund of the European Union: a way to Making Europe, and by the University of Fribourg (Fribourg, Switzerland). A short stay of JF at the University of Fribourg was supported by a grant from the Sociedad Española de Enfermedades Infecciosas y Microbiología Clínica (SEIMC). IM was the recipient of a predoctoral grant from the Fundación para el Fomento en Asturias de la Investigación Científica Aplicada y la Tecnología [FICYT BP09-069].

Competing interests: None declared.

Ethical approval: Not required.

\section{References}

[1] Davin-Regli A, Pagès JM. Enterobacter aerogenes and Enterobacter cloacae; versatile bacterial pathogens confronting antibiotic treatment. Front Microbiol 2015;6:392.

[2] Cantón R, Novais A, Valverde A, Machado E, Peixe L, Baquero F, et al. Prevalence and spread of extended-spectrum $\beta$-lactamase-producing Enterobacteriaceae in Europe. Clin Microbiol Infect 2008;14(Suppl. 1):144-53.

[3] Potron A, Poirel L, Rondinaud E, Nordmann P. Intercontinental spread of OXA$48 \beta$-lactamase-producing Enterobacteriaceae over a 11-year period, 2001 to 2011. Euro Surveill 2013;18, pii:20549.

[4] Hopkins KL, Liebana E, Villa L, Batchelor M, Threlfall EJ, Carattoli A. Replicon typing of plasmids carrying CTX-M or CMY $\beta$-lactamases circulating among Salmonella and Escherichia coli isolates. Antimicrob Agents Chemother 2006;50:3203-6.

[5] Fernández J, Montero I, Fleites A, Rodicio MR. Cluster of Escherichia coli isolates producing a plasmid-mediated OXA-48 $\beta$-lactamase in a Spanish hospital in 2012. J Clin Microbiol 2014:52:3414-7.

[6] Poirel L, Bonnin RA, Nordmann P. Genetic features of the widespread plasmid coding for the carbapenemase OXA-48. Antimicrob Agents Chemother 2012;56:559-62.

[7] Clinical and Laboratory Standards Institute. Performance standards for antimicrobial susceptibility testing; approved standard-twenty-fourth informational supplement. Document M100-S24. Wayne, PA: CLSI; 2014.

[8] Nordmann P, Poirel L, Dortet L. Rapid detection of carbapenemase-producing Enterobacteriaceae. Emerg Infect Dis 2012;18:1503-7.

[9] Minarini L, Poirel L, Cattoir V, Darini AL, Nordmann P. Plasmid-mediated quinolone resistance determinants among enterobacterial isolates from outpatients in Brazil. J Antimicrob Chemother 2008;62:474-8.

[10] Girlich D, Poirel L, Nordmann P. Clonal distribution of multidrug-resistant Enterobacter cloacae. Diagn Microbiol Infect Dis 2015;81:264-8.

[11] Adler A, Solter E, Masarwa S, Miller-Roll T, Abu-Libdeh B, Khammash H, et al. Epidemiological and microbiological characteristics of an outbreak caused by OXA-48-producing Enterobacteriaceae in a neonatal intensive care unit in Jerusalem, Israel. J Clin Microbiol 2013;51:2926-30.

[12] Oteo J, Cercenado E, Vindel A, Bautista V, Fernandez-Romero S, Saez $\mathrm{D}$, et al. Outbreak of multidrug-resistant CTX-M-15-producing Enterobacter cloacae in a neonatal intensive care unit. J Med Microbiol 2013;62: 571-5.

[13] Pasanen T, Jalava J, Horsma J, Salo E, Pakarinen M, Tarkka E, et al. An outbreak of CTX-M-15-producing Escherichia coli, Enterobacter cloacae, and Klebsiella in a children's hospital in Finland. Scand J Infect Dis 2014;46: 225-30.

[14] Potron A, Poirel L, Nordmann P. Derepressed transfer properties leading to the efficient spread of the plasmid encoding carbapenemase OXA-48. Antimicrob Agents Chemother 2014;58:467-71

[15] Izdebski R, Baraniak A, Herda M, Fiett J, Bonten MJ, Carmeli Y, et al. MLST reveals potentially high-risk international clones of Enterobacter cloacae. J Antimicrob Chemother 2015;70:48-56. 